\title{
PENGEMBANGAN PENDIDIKAN KARAKTER
}

\section{DALAM PEMBELAJARAN PAI PADA SEKOLAH MENENGAH}

\author{
Saridudin \\ Puslitbang Pendidikan Agama dan Keagamaan \\ Badan Litbang dan Diklat Kementerian Agama RI \\ dudinsaridudn@gmail.com
}

\begin{abstract}
Abstrak: Pendidikan karakter adalah sebuah sistem untuk mengembangkan nilai-nilai karakter siswa yang meliputi komponen pengetahuan, kesadaran atau kemauan, dan tindakan untuk diimplementasikan ke dalam agama, diri sendiri, masyarakat umum, lingkungan, dan bangsa sehingga menjadi manusia yang paripurna (insan kamil). Dalam pelaksanaan pendidikan karakter di sekolah, setiap stakeholder pembelajaran harus terlibat dalam proses tersebut, termasuk komponen pendidikan, yaitu kurikulum, pembelajaran dan proses evaluasi, kualitas hubungan, penanganan pelajaran atau manajemen, manajemen sekolah, pelaksanaan kegiatan ko-kurikuler, penggunaan fasilitas, pendanaan, dan kinerja dari setiap dan semua komponen sekolah. Pengembangan pendidikan karakter dalam pembelajaran PAI pada sekolah menengah perlu dilakukan mengingat Agama bukan hanya sebuah dogma yang harus diajarkan, tetapi lebih jauh dari itu adalah internalisasi nilai-nilai yang keberadaanya melekat dalam hati dan menjiwai serta terpancar dalam seluruh aspek prilaku kehidupan seharihari. Untuk merealisasikan nilai-nilai karakter dalam diri siswa Sekolah Menengah dalam kehidupan sehari-hari baik di sekolah maupun di luar sekolah, bisa ditempuh melalui berbagai bentuk pendekatan pembelajaran yaitu Pembelajaran Kontekstual (Contextual Teaching and Learning), Pembelajaran Kooperatif (Cooperative Learning), Pembelajaran Inkuiri (Inquiry Learning), Pembelajaran Model PAKEM (Pembelajaran Aktif, Kreatif, Efektif, dan Menyenangkan), Pemodelan, dan Pembelajaran Afektif (Model konsiderasi, Model pembentukan rasional, Klarifikasi nilai, Pengembangan moral kognitif dan Model nondirektif).
\end{abstract}

Key Words: Pendidikan Karakter, PAI, Sekolah Menengah

\section{A. Pendahuluan}

Pengembangan pendidikan karakter (character education) dalam pembelajaran PAI pada sekolah menengah dalam konteks masyarakat Indonesia sekarang ini sangat relevan untuk mengatasi berbagai krisis moral yang sedang melanda negara ini. Krisis tersebut antara lain berupa meningkatnya tawuran pelajar, pergaulan bebas remaja, maraknya angka kekerasan anak-anak dan remaja, pencurian, kebiasaan menyontek, penyalahgunaan obat-obatan, pornografi, dan yang tak kalah pentingnya adalah kejahatan korupsi yang dilakukan aparat negara yang sudah menjadi masalah sosial yang hingga saat ini belum dapat diatasi secara tuntas. 
Permasalahan yang melanda pelajar Indonesia juga elite politiknya mengindikasikan bahwa pendidikan agama dan moral yang didapatkan di bangku sekolah atau kuliah tidak berdampak positif terhadap perubahan perilaku manusia Indonesia. Bahkan yang terlihat adalah begitu banyak manusia Indonesia yang tidak koheren antara ucapan dan tindakannya. Kondisi demikian, diduga berawal dari apa yang dihasilkan oleh dunia pendidikan.

Demoralisasi terjadi karena proses pembelajaran cenderung mengajarkan pendidikan moral dan budi pekerti sebatas teks dan kurang mempersiapkan siswa untuk menyikapi dan menghadapi kehidupan yang kontradiktif (Akhwan, 2011). Dalam konteks pendidikan formal di sekolah/madrasah, bisa jadi salah satu penyebabnya karena pendidikan di Indonesia lebih menitikberatkan kepada pengembangan intelektual atau kognitif semata, sedangkan aspek soft skill atau non-akademik sebagai unsur utama pendidikan moral belum diperhatikan.

Padahal, pencapaian hasil belajar siswa tidak dapat hanya dilihat dari ranah kognitif dan psikomotorik, sebagaimana selama ini terjadi dalam praktik pendidikan kita, tetapi harus juga dilihat dari hasil afektif, Ketiga ranah berhubungan secara resiprokal, meskipun kekuatan hubungannya bervariasi dari satu kasus ke kasus yang lain. Beberapa hasil penelitian menunjukkan bahwa efektivitas pencapaian hasil kognitif terjadi sejalan dengan efektivitas pencapaian ranah afektif.

Implementasi pendidikan karakter pada sekolah menengah baik SMA, MA atau SMK harus menjadi solusi alternatif dalam memecahkan berbagai permasalahan moral pelajar dan bangsa, maka diperlukan kerja keras semua pihak, terutama terhadap program-program yang memiliki kontribusi besar terhadap peradaban bangsa. Namun, penerapan pendidikan karakter pada level sekolah menengah memerlukan pemahaman tentang konsep, teori, metodologi dan aplikasi yang relevan dengan pembentukan karakter (character building) dan pendidikan karakter (character education).

Berdasarkan persoalan di atas, tulisan ini akan membahas tentang apa yang dimaksud pendidikan karakter serta bagaimana pengembangannya dalam pembelajaran Pendidikan Agama Islam pada Sekolah Menengah. 


\section{B. Konsep Pendidikan Karakter}

\section{Pengertian Karakter}

Akar kata karakter berasal dari bahasa latin kharakter, kharassein, kharax, yang maknanya "tools for making", "to engrave", dan "pointed stake" (Leo Agung, 2011). Kata karakter berasal dari bahasa Perancis caractere yang diadopsi ke dalam bahasa Inggris menjadi "character", dan diindonesiakan menjadi karakter (Andrias Harefa, 2009) yang diartikan sebagai tabiat, watak, sifat kejiwaan, akhlak atau budi pekerti yang membedakan seseorang dari pada yang lain.

Karakter adalah cara berpikir dan berperilaku individu untuk hidup dan bekerjasama dalam lingkungan keluarga, masyarakat, bangsa dan negara. Seorang idividu yang berkarakter baik adalah individu yang membuat keputusan dan siap bertanggung jawab dengan yang dihasilkan dari keputusan tersebut (Suyanto, 2010). Karakter yang baik adalah sebuah konsep yang yang mengandung knowing good, embracing good and doing well (Katilmis, 2011,854).

Sumantri (2010: 6) mengatakan: "Character is what you, do when no one"s watching, character is what you are in the dark, character is needed to lead a good life, character is higher than intellect, character is the jewel of human life, character is the only secure foundation of state, character is in the eye of the beholder, character is defined by what you do, character is shaped in the womb". Karakter adalah watak, tabiat, sikap atau perilaku yang telah menjadi bagian yang tidak terpisahkan dari individu, sikap tersebut dapat muncul secara spontan baik ada orang lain yang melihat atau pun tidak, baik di suasana yang terang ataupun di kegelapan dan karakter baik dibutuhkan untuk menjalani kehidupan yang lebih baik, dan merupakan permata kehidupan sehingga menjadikan negara yang aman.

Wynne dalam (Sauri, 2010) memahami istilah karakter memiliki dua pengertian. Pertama, ia menunjukkan bagaimana seseorang bertingkah laku. Apabila seseorang berperilaku tidak jujur, kejam, atau rakus, tentulah orang tersebut memanifestasikan karakter buruk. Sebaliknya, apabila seseorang berperilaku jujur, suka menolong, tentulah orang tersebut memanifestasikan karakter mulia. Kedua, istilah karakter erat kaitannya dengan personality. Seseorang baru bisa disebut orang yang berkarakter (a person of character) apabila tingkah lakunya sesuai kaidah moral. 


\section{Pendidikan Karakter}

Hoge dalam Agboola \& Tsai (2012) mendefinisikan pendidikan karakter as a way of adjusting the behaviors of the students, in order to become good citizens of the future, these students were being instructed, guided, and toward having some sets of prescribed behaviors. Marshall, Caldwell, and Fos-ter (2011) mengklaim bahwa "character education is perpetually believed, to some kind of ways through which the students are being nurtured in the direction of seeing things in different perspectives; in other words, training them is always to exert maturity while in the mist of challenging situations."

U.S. Department of Education (2005) mendefinisikan pendidikan karakter sebagai "an explicit learning process from which students in a school community understand, accept, and act on ethical values such as respect for others, justice, civic virtue and citizenship, and responsibility for self and others." Ada tiga fokus pendidikan karakter. Pertama, pendidikan karakter berfokus pada pengajaran nilai-nilai. Kedua, berfokus pada nilai klarifikasi. Dan yang ketiga, berfokus pada pengembangan moral Kohlberg (Leo Agung, 2011).

Pendekatan holistik dan seimbang terhadap pendidikan karakter menurut menurut Guidry $(2006,23)$ memilki ciri-ciri sebagai berikut:

1. Allows for individual liberation.

2. Avoids indoctrination and manipulation.

3. Is rooted in empirical evidence.

4. Does not stray toward relativism.

5. Takes place in a social context.

6. Unites moral and academic work.

7. Allows for diverse perspectives.

8. Provides for an evaluation of potential consequences.

9. Provides outlets for reconciliation of diverse perspectives.

10. Comes to a substantive conclusion through development of a principle.

Pendidikan karakter yang berfokus pada nilai pengajaran terutama mencakup konten nilai khusus, serta berbagai kualitas moral seperti kejujuran, kemurahan hati, dan lain-lain untuk dipelajari dan dipahami oleh siswa. Nilai klarifikasi terutama mencakup identifikasi moral dan nilai seleksi. Dan pengembangan karakter moral adalah untuk mencerminkan nilai penerimaan dan motivasi, dan aspek individu lain yang relatif stabil yang dapat mengarahkan tindakan individu. Fokus pertama adalah 
tentang intelektual, fokus kedua adalah tentang perilaku, yang memprioritaskan pada pemahaman, pengembangan nilai dan seleksi, sedangkan fokus ketiga adalah tentang pengembangan motivasi interval dalam mengembangkan nilai-nilai sesuai dengan perkembangan moral individu.

Pendidikan karakter adalah sebuah sistem untuk mengembangkan nilai-nilai karakter siswa yang meliputi komponen pengetahuan, kesadaran atau kemauan, dan tindakan untuk diimplementasikan ke dalam agama, diri sendiri, masyarakat umum, lingkungan, dan bangsa sebagai manusia yang paripurna. Dalam pelaksanaan pendidikan karakter di sekolah, setiap stakeholder pembelajaran harus terlibat dalam proses tersebut, termasuk komponen pendidikan, yaitu kurikulum, pembelajaran dan proses evaluasi, kualitas hubungan, penanganan pelajaran atau manajemen, manajemen sekolah, pelaksanaan kegiatan ko-kurikuler, penggunaan fasilitas, pendanaan, dan kinerja dari setiap dan semua komponen sekolah.

Pendidikan karakter adalah plus pendidikan moral, yang meliputi kognitif, emosi, dan aspek tindakan. Menurut Lickona (1991), tanpa ketiga aspek tersebut, pendidikan karakter tidak akan efektif. Dengan pendidikan karakter sistematis dan berkesinambungan, siswa akan menjadi cerdas secara emosional. Kecerdasan emosional adalah fondasi penting bagi masa depan siswa, sehingga siswa akan lebih sukses dalam menghadapi setiap tantangan kehidupan, termasuk tantangan akademis.

Nilai-nilai karakter yang perlu ditanamkan kepada anak-anak adalah nilainilai karakter universal yang diakui, dijunjung tinggi dan mampu menjadi perekat bagi seluruh anggota masyarakat dengan berbagai latar belakang agama, suku dan budaya.

Indonesia Haritage Foundation dalam Megawangi (2004: 81) telah menyusun serangkaian nilai yang selayaknya diajarkan kepada anak-anak, yang kemudian dirangkum menjadi sembilan pilar karakter, yaitu: a) cinta Tuhan dan kebenaran (love Allah, trust, reverence, loyalty). b) tanggung jawab, kedisiplinan, dan kemandirian (responsibility, excellence, self reliance, discipline, orderliness). c) amanah (trustworthiness, reliability,honesty). d) hormat dan santun (respect, courtessy, obedience). e) kasih sayang, kepedulian, dan kerjasama (love, compassion, caring, empathy, generousity, moderation, cooperation). f) percaya diri, kreatif, dan pantang menyerah (confidence, assertiveness, creativity, resourcefulness, courage, deterination and enthusiasm).g) keadilandan kepemimpinan (justice,fairness,mercy, leardership). 
Komalasari (2011:424) mengidentifikasi sepuluh karakter yang harus dikembangkan yaitu:1) respect; 2) responsibility; 3) honesty; 4) empathy; 5) fairness; 6) initiative; 7) courage; 8) perseverance; 9) optimism; and 10) integrity.

Desain Induk Pembangunan Karakter Bangsa (2010) memiliki 18 Nilai- nilai karakter yang menjadi indikator pengembangan pendidikan budaya dan karakter bangsa yaitu: Religius, jujur, toleransi, disiplin, kerja keras, kreatif, mandiri, demokratis, rasa ingin tahu, semangat kebangsaan, cinta tanah air, menghargai prestasi, bersahabat/komunikatif, cinta damai, gemar membaca, peduli lingkungan, peduli sosial, dan tanggung jawab.

Nilai-nilai yang tertuang baik yang diungkapkan Megawangi dengan sembilan pilar karakter, Komalasari dengan 10 karakter atau 18 karakter dalam Desain Induk Pendidikan Karakter Bangsa pada prinsipnya sangat tepat digunakan sebagai pembentukan dasar kepribadian, pengembangan, dan pembentukan kepribadian anak. Proses pembelajaran dengan memberikan rangsangan belajar bagi anak sesuai dengan kecerdasan yang dimiliki anak akan sangat menentukan masa depan anak. Sebab, anak-anak pada masa usia dini sangat mempercayai orang tua/guru sehingga penekanan nilai-nilai tersebut menjadikannya pribadi berkarakter.

\section{Pendidikan Agama Islam}

Zakiah Daradjat $(1992,28)$ merumuskan Pendidkan Agama Islam sebagai: (a) Pendidikan agama Islam adalah usaha berupa bimbingan dan asuhan terhadap anak didik agar setelah selesai dari pendidikannya dapat memahami dan mengamalkan ajaran agama Islam serta menjadikannya sebagai pandangan hidup (way of life). (b) Pendidikan Agama Islam adalah pendidikan yang dilaksanakan berdasarkan ajaran Islam. (c) Pendidikan Agama Islam adalah pendidikan dengan melalui ajaran-ajaran agama Islam, yaitu berupa bimbingan dan asuhan terhadap anak didik agar nantinya setelah selesai dari pendidikan ia dapat memahami, menghayati dan mengamalkan ajaran agama Islam yang telah diyakini menyeluruh, serta menjadikan keselamatan hidup di dunia maupun di akhirat kelak."

Sementara pengertian pendidikan agama Islam secara formal dalam kurikulum berbasis kompetensi disebutkan bahwa: Pendidikan agama Islam adalah upaya sadar dan terencana dalam menyiapkan peserta untuk mengenal, memahami, menghayati hingga mengimani, bertakwa dan berakhlak mulia dalam mengamalkan ajaran agama Islam dari sumber utamanya; kitab suci Al-Qur'an dan Hadits, melalui kegiatan 
bimbingan, pengajaran, latihan serta penggunaan pengalaman. Dibarengi tuntutan untuk menghormati penganut agama dalam masyarakat hingga terwujudnya kesatuan dan persatuan bangsa ( Depdiknas, 2003, 7).

Pengertian tersebut sesuai dengan rumusan UU Nomor 20 Tahun 2003 tentang Sistem Pendidikan Nasional dalam penjelasan UUSPN mengenai pendidikan agama dijelaskan bahwa pendidikan agama dimaksudkan untuk membentuk peserta didik menjadi manusia yang beriman dan bertakwa kepada Tuhan Yang Maha Esa serta berakhlak mulia.

Dari pengertian-pengertian di atas dapat ditarik suatu kesimpulan bahwa Pendidikan Agama Islam adalah segenap kegiatan yang dilakukan seseorang untuk membantu seorang atau sekelompok peserta didik dalam menanamkan dan menumbuhkembangkan ajaran Islam dan nilai-nilainya untuk dijadikan sebagai pandangan hidupnya, yang diwujudkan dalam sikap hidup dan dikembangkan dalam keterampilan hidupnya sehari-hari.

\section{Pengembangan Pendidikan Karakter dalam Pembelajaran PAI pada Sekolah Menengah}

Pengembangan pendidikan karakter dalam pembelajran PAI pada sekolah menengah meliputi pengembangan 17 karakter utama, yaitu: kereligiusan, kejujuran, kecerdasan, ketangguhan, tanggung jawab, kepedulian, kedemokratisan, kesantunan, kedisiplinan, cinta ilmu, keingintahuan, percaya diri, menghargai keberagaman, kepatuhan terhadap aturan sosial, gaya hidup sehat, kesadaran akan hak dan kewajiban, dan kerja keras (Kemendiknas, 2010) . Jadi, semua nilai yang 17 ini termasuk nilai-nilai karakter utama yang harus terimplementasi dalam kehidupan sehari-hari. Dari 17 nilai itu ada 6 nilai karakter pokok yang menjadi pangkal tolak pengembangan karakter pada Sekolah menengah, yaitu kereligiusan, kejujuran, kecerdasan, ketangguhan, kedemokratisan, dan kepedulian.

Adapun indikator-indikator yang bisa dilihat dari nilai-nilai karakter utama di atas di antaranya adalah:

\begin{tabular}{|r|l|rl|}
\hline No. & Nilai Karakter & \multicolumn{2}{|c|}{ Indikator } \\
\hline 1. & Kereligiusan & 1) & $\begin{array}{l}\text { menjalankan perintah-perintah Allah (agama) baik } \\
\text { dalam beribadah maupun bermuamalah, dengan } \\
\end{array}$ \\
& & & $\begin{array}{l}\text { didasari iman (aqidah) yang benar, } \\
\text { menjauhi larangan-larangan Allah (agama) baik yang }\end{array}$ \\
\hline
\end{tabular}




\begin{tabular}{|c|c|c|c|}
\hline & & 3) & $\begin{array}{l}\text { termasuk dalam dosa-dosa besar maupun dosa-dosa } \\
\text { kecil, } \\
\text { bersikap dan berperilaku yang sesuai dengan } \\
\text { ketentuan-ketentuan atau hukum-hukum agama, } \\
\text { tidak melakukan perbuatan-perbuatan sehari-hari } \\
\text { yang melanggar hukum-hukum agama. }\end{array}$ \\
\hline 2. & Kejujuran & $\begin{array}{l}\text { 4) } \\
\text { 5) } \\
\text { 6) }\end{array}$ & $\begin{array}{l}\text { selalu mengatakan apa yang sebenarnya terjadi, } \\
\text { selalu mengatakan sesuai dengan apa yang dilakukan, } \\
\text { selalu mengerjakan tugas-tugas guru seperti } \\
\text { pekerjaan rumah dan lain-lain sesuai dengan } \\
\text { ketentuan yang ada. } \\
\text { tidak berbohong kepada siapa pun, } \\
\text { tidak mengambil sesuatu yang bukan menjadi } \\
\text { haknya, } \\
\text { tidak menyontek dalam mengerjakan ujian atau } \\
\text { ulangan sekolah, }\end{array}$ \\
\hline 3. & Kecerdasan & $\begin{array}{l}\text { 1) } \\
\text { 2) } \\
\text { 3) }\end{array}$ & $\begin{array}{l}\text { mampu mengerjakan suatu pekerjaan dengan cermat, } \\
\text { tepat, dan cepat. } \\
\text { mampu menjawab soal-soal ujian (ulangan) dengan } \\
\text { cepat, tepat, dan benar, } \\
\text { mampu menjawab pertanyaan dengan tepat, } \\
\text { mampu mengambil keputusan yang tepat. }\end{array}$ \\
\hline 4. & Ketangguhan & $\begin{array}{l}\text { 1) } \\
\text { 2) } \\
\text { 3) } \\
\text { 5) }\end{array}$ & $\begin{array}{l}\text { tidak pernah putus asa dalam menghadapi berbagai } \\
\text { persoalan di sekolah dan keluarga, } \\
\text { sanggup menerima kegagalan dan berusaha untuk } \\
\text { memperbaikinya, } \\
\text { tidak putus asa ketika tidak naik kelas atau tidak lulus } \\
\text { ujian, } \\
\text { kuat dan tabah menghadapi berbagai cobaan dan } \\
\text { tantangan, } \\
\text { berusaha keras untuk bisa melepaskan diri dari } \\
\text { masalah yang dihadapi. }\end{array}$ \\
\hline 5. & Kedemokratisan & $\begin{array}{l}\text { 3) } \\
\text { 4) } \\
\text { 5) }\end{array}$ & $\begin{array}{l}\text { menjunjung tinggi kebersamaan, baik di sekolah } \\
\text { maupun di tengah keluarga, } \\
\text { mengambil keputusan secara bersama-sama baik di } \\
\text { sekolah, di tengah keluarga, maupun dengan teman- } \\
\text { teman di masyarakat, } \\
\text { menghormati keputusan bersama meskipun tidak } \\
\text { sesuai dengan yang diinginkan, } \\
\text { tidak memaksakan pendapat kepada orang lain, } \\
\text { berdiskusi dengan baik dan tidak emosional. }\end{array}$ \\
\hline 6. & Kepedulian & $\begin{array}{l}\text { 1) } \\
\text { 2) } \\
\text { 3) } \\
\text { 4) } \\
\text { 5) } \\
\text { 6) } \\
\text { 7) }\end{array}$ & $\begin{array}{l}\text { tanggap akan lingkungan sekitar, } \\
\text { mematikan lampu, listrik, kipas/AC, kran air, atau } \\
\text { alat-alat lain yang tidak digunakan, } \\
\text { membersihkan ruang kelas dan papan tulis yang } \\
\text { kotor, } \\
\text { merapikan meja kursi yang berserakan, } \\
\text { menjaga lingkungan sekolah tetap bersih, } \\
\text { membantu orang lain yang butuh pertolongan, } \\
\text { mengingatkan orang lain yang dalam keadaan }\end{array}$ \\
\hline
\end{tabular}




\begin{tabular}{|c|c|c|c|}
\hline & & & berbahaya. \\
\hline 7. & Tanggung jawab & 5) & $\begin{array}{l}\text { menaati dan melaksanakan hukum-hukum dan } \\
\text { aturan-aturan yang berlaku, } \\
\text { menaati dan melaksanakan kesepakatan dalam } \\
\text { keluarga, } \\
\text { berani mengambil risiko atas perbuatan yang } \\
\text { dilakukan, } \\
\text { patuh dan melaksanakan semua kewajiban sekolah } \\
\text { dan di luar sekolah, } \\
\text { tidak mengalihkan tugas dan kewajiban kepada orang } \\
\text { lain. }\end{array}$ \\
\hline 8. & $\begin{array}{l}\text { Kesadaran akan } \\
\text { hak dan } \\
\text { kewajiban }\end{array}$ & $\begin{array}{l}\text { 1) } \\
\text { 2) }\end{array}$ & $\begin{array}{l}\text { menjunjung tinggi keadilan, } \\
\text { menjalankan kewajiban tanpa mengganggu hak orang } \\
\text { lain, } \\
\text { mendahulukan pelaksanaan kewajiban sebelum } \\
\text { menuntut hak, } \\
\text { menghormati hak-hak orang lain, } \\
\text { tidak mengganggu orang lain dalam melaksanakan } \\
\text { kewajiban. }\end{array}$ \\
\hline 9. & Kesantunan & $\begin{array}{l}\text { 1) } \\
\text { 2) } \\
\text { 3) }\end{array}$ & $\begin{array}{l}\text { bertutur kata dengan lemah lembut, } \\
\text { mengucapkan salam ketika bertemu orang lain, } \\
\text { berjalan dengan penuh kesopanan dan tidak } \\
\text { menyombongkan diri, } \\
\text { memilih kata-kata atau bahasa yang tepat ketika } \\
\text { berbicara, terutama dengan orang yang dihormati } \\
\text { seperti orang tua dan guru, } \\
\text { memohon izin ketika akan keluar dari ruangan kelas } \\
\text { ketika pembelajaran berlangsung, }\end{array}$ \\
\hline 10. & Kerja keras & $\begin{array}{l}\text { 1) } \\
\text { 2) }\end{array}$ & $\begin{array}{l}\text { selalu belajar dengan giat, } \\
\text { mengerjakan tugas dan kewajiban di sekolah secara } \\
\text { maksimal, } \\
\text { tidak pernah menyerah dalam menghadapi berbagai } \\
\text { tantangan dan hambatan di sekolah dan keluarga, } \\
\text { tidak menyia-nyiakan waktu dan kesempatan, } \\
\text { selalu membantu orang tua di rumah. }\end{array}$ \\
\hline 11. & Kedisiplinan & $\begin{array}{l}\text { 1) } \\
\text { 2) } \\
\text { 3) } \\
\text { 4) }\end{array}$ & $\begin{array}{l}\text { datang dan pulang sekolah tepat waktu, } \\
\text { memakai seragam sesuai ketentuan sekolah, } \\
\text { melaksanakan shalat/ibadah tepat waktu, } \\
\text { mengatur waktu untuk belajar dan untuk yang } \\
\text { lainnya, } \\
\text { makan dan tidur tepat waktu. }\end{array}$ \\
\hline 12. & $\begin{array}{l}\text { Menghargai } \\
\text { keberagaman }\end{array}$ & 1) & $\begin{array}{l}\text { mengakui adanya perbedaan dalam berbagai hal di } \\
\text { sekolah, } \\
\text { menjalankan aktivitas keagamaan di sekolah tanpa } \\
\text { menyinggung dan mengganggu orang lain, } \\
\text { menghormati orang lain yang berbeda dalam } \\
\text { berkeyakinan dan beragama, } \\
\text { menghormati orang lain yang berbeda dalam } \\
\text { menjalankan tradisi dan budaya, } \\
\text { tidak memaksakan kehendak kepada orang lain. }\end{array}$ \\
\hline
\end{tabular}




\begin{tabular}{|c|c|c|}
\hline 13. & Cinta ilmu & $\begin{array}{l}\text { 1) suka membaca buku, termasuk al-Quran dan hadis, } \\
\text { 2) memiliki buku-buku ilmu pengetahuan yang } \\
\text { dibutuhkan, } \\
\text { 3) tidak membuang buku-buku yang bermanfaat, } \\
\text { 4) suka berdiskusi tentang ilmu pengetahuan, } \\
\text { 5) suka melakukan perjalanan (bepergian) dalam } \\
\text { mencari ilmu. }\end{array}$ \\
\hline 14. & Keingintahuan & $\begin{array}{l}\text { 1) tidak pernah merasa puas dalam mencari ilmu, } \\
\text { 2) suka bertanya kepada orang lain, } \\
\text { 3) suka membaca koran dan sumber berita lainnya, } \\
\text { 4) suka mendengarkan berita lewat radio, televisi, } \\
\text { maupun media yang lain, } \\
\text { 5) suka membaca al-Quran, hadis, dan kitab-kitab } \\
\text { sebagai sumber ilmu pengetahuan. }\end{array}$ \\
\hline 15. & Percaya diri & $\begin{array}{l}\text { 1) merasa senang dengan keberadaannya. } \\
\text { 2) bangga menjai siswa di sekolahnya } \\
\text { 3) tidak merasa minder di hadapan siswa atau orang } \\
\text { lain. } \\
\text { 4) selalu belajar untuk meningkatkan kualitas diri, } \\
\text { 5) tidak ragu dalam mengambil keputusan, } \\
\text { 6) suka bergaul dengan orang lain. }\end{array}$ \\
\hline 16. & $\begin{array}{l}\text { Kepatuhan } \\
\text { terhadap aturan } \\
\text { sosial }\end{array}$ & $\begin{array}{l}\text { 1) mengikuti kerja bakti di lingkungannya, } \\
\text { 2) mengikuti berbagai kegiatan di sekolah dan di luar } \\
\text { sekolah, } \\
\text { 3) tidak melakukan sesuatu yang melanggar } \\
\text { kepentingan umum, } \\
\text { 4) ikut serta dalam menjaga ketenangan dan keamanan } \\
\text { lingkungan, } \\
\text { 5) suka bekerja sama dengan masyarakat sekitar. }\end{array}$ \\
\hline 17. & Gaya hidup sehat & $\begin{array}{l}\text { 1) mengkonsumsi makanan dan minuman yang halal } \\
\text { dan baik } \\
\text { 2) makan dan minum secukupnya, } \\
\text { 3) bekerja dan beristirahat secukupnya, } \\
\text { 4) tidak berangan-angan yang berlebihan, } \\
\text { 5) menjaga anggota badan, pakaian, dan lingkungan } \\
\text { selalu bersih, } \\
\text { 6) menjauhi merokok, } \\
\text { 7) menjauhi miras dan narkoba, } \\
\text { 8) tidak bertato. }\end{array}$ \\
\hline
\end{tabular}

\section{E. Kegiatan Pembelajaran yang Mengembangkan Karakter pada Pembelajaran Pendidikan Agama Islam pada Sekolah Menengah}

Untuk merealisasikan nilai-nilai karakter dalam diri siswa Sekolah Menengah dalam kehidupan sehari-hari baik di sekolah maupun di luar sekolah, bisa ditempuh melalui berbagai bentuk kegiatan pembelajaran di kelas. Kegiatan pembelajaran yang 
efektif dan efisien hendaknya diupayakan dalam merealisasikan nilai-nilai karakter tersebut. Di bawah ini akan dikemukakan beberapa contoh kegiatan pembelajaran yang cukup efektif dan efisien di kelas.

\section{Pembelajaran Kontekstual (Contextual Teaching and Learning)}

Pembelajaran model ini dilakukan dengan menghubungkan tema atau materi yang dikaji dengan konteks kehidupan sehari-hari, terutama kehidupan peserta didik. SK/KD yang dikaji hendaknya dikaitkan dengan permasalahan yang aktual yang benarbenar terjadi dan dialami peserta didik. Dengan cara ini, peserta didik akan langsung mengalami apa yang dipelajari sehingga peserta didik memiliki motivasi besar untuk memahaminya dan pada akhirnya terdorong untuk mempraktikkannya. Sebagai contoh ketika mengajarkan aqidah dengan tema iman kepada kitab-kitab Allah, peserta didik diajak langsung melihat bukti adanya kitab-kitab Allah tersebut, misalnya al-Quran yang merupakan salah satu kitab Allah dan menjadi kitab suci umat Islam. Peserta didik kemudian diajak untuk melihat al-Quran lalu diajak berdiskusi tentang al-Quran dan peserta didik dimotivasi agar bisa membaca, memahami, dan mengamalkan isi kandungan al-Quran sedikit demi sedikit.

Contoh lain misalnya ketika mengajarkan fikih tentang thaharah (bersuci) peserta didik diajak langsung praktik tentang bagaimana membersihkan kotoran (najis) dan juga praktik wudlu dan mandi untuk menghilangkan hadas. Selanjutnya anak diajak untuk selalu berpola hidup sehat dan bersih dengan menjelaskan manfaat dan hikmah kebersihan dan kesehatan serta menyebutkan contoh-contoh akibat baik dari berpola sehat dan bersih dan akibat buruk mengabaikan pola sehat dan bersih. Dengan model pembelajaran ini cukup mudah bagi guru memotivasi peserta didik untuk bersikap dan berperilaku yang menunjukkan nilai-nilai karakter sesuai dengan tema atau materi yang dikaji.

\section{Pembelajaran Kooperatif (Cooperative Learning)}

Pembelajaran kooperatif adalah pembelajaran yang menekankan kerjasama di antara peserta didik di kelas. Banyak model pembelajaran yang bisa dilakukan dalam rangka pembelajaran kooperatif, misalnya model diskusi kelompok, diskusi kelas, Team Game Tournament (TGT), model Jigsaw, Learning Together (belajar bersama), dan lain sebagainya. Sebagai contoh, untuk mempelajari sejarah Nabi Muhammad saw. peserta didik melakukan diskusi kelompok dengan tema-tema diskusi yang sudah ditentukan, 
sehingga dalam waktu yang singkat bisa diperoleh informasi yang lebih komprehensif tentang sejarah Nabi Muhammad saw.

Melalui model ini guru bisa mengamati bagaimana peserta didik berdiskusi sambil memberikan penilaian proses terutama dalam penerapan nilai-nilai karakter, misalnya kecerdasan, keingintahuan, kesantunan, kedemokratisan, dan lain sebagainya. Peserta didik juga diminta untuk meneladani karakter-karakter mulia yang ada pada diri

Nabi Muhammad saw. seperti kejujuran, kecerdasan, kesabaran, kesantunan, kepedulian, dan ketangguhan.

\section{Pembelajaran Inkuiri (Inquiry Learning)}

Pembelajaran inkuiri adalah satu model pembelajaran yang dikemas sedemikian rupa agar peserta didik mampu menemukan pengetahuan atau konsep-konsep yang ada dalam mata pelajaran tertentu secara mandiri melalui berbagai fenomena yang dipelajari. Melalui model ini peserta didik dikondisikan agar memiliki nilai-nilai kerja keras, meningkat rasa keingintahuan dan kecerdasannya, serta kecintaannya terhadap ilmu. Tidak semua SK/KD dalam mata pelajaran Pendidikan Agama Islam bisa dicapai dengan model pembelajaran ini. Di antara contoh kompetensi yang bisa dicapai melalui model ini adalah kompetensi yang terkait dengan aqidah, muamalah, dan sejarah peradaban Islam. Cukup banyak materi atau kompetensi dalam tiga bidang itu yang bisa dikaji melalui model pembelajaran ini.

\section{Pembelajaran Model PAKEM (Pembelajaran Aktif, Kreatif, Efektif, dan Menyenangkan)}

Prinsip-prinsip yang menonjol dalam pembelajaran model PAKEM di antaranya adalah peserta didik harus aktif dalam pembelajaran ini dan pembelajaran harus menyenangkan peserta didik. Pembelajaran harus dikemas agar peserta didik benarbenar aktif dan kreatif, misalnya dengan menkondisikan peserta didik aktif belajar dan melakukan sesuatu. Guru tidak lagi ceramah yang membuat peserta didik hanya pasif mendengarkan ceramahnya. Ceramah diperlukan bila perlu. Untuk membuat peserta didik senang dalam belajar maka guru harus memfasilitasi peserta didik dengan berbagai media atau alat yang mendukung pembelajaran, misalnya dengan media komputer (laptop), LCD, atau media lain yang memungkinkan peserta didik untuk senang dalam belajar. Yang juga harus diperhatikan bahwa pembelajaran harus tetap efektif, yakni mencapai tujuan yang direncanakan. Sebagai contoh, ketika 
membelajarkan al-Quran, peserta didik dikondisikan untuk belajar langsung melafalkan ayat-ayat al-Quran dibantu dengan media yang mendukung. Guru terus memantau peserta didik dalam proses pembelajaran agar efektif.

\section{Pemodelan}

Dalam pembelajaran mata pelajaran Pendidikan Agama Islam (PAI) terutama untuk pembinaan karakter para siswa, pemodelan (pemberian uswah hasanah/teladan yang baik) merupakan metode yang cukuf efektif. Yang menjadi model utama dalam hal ini adalah guru agama dan semua guru yang ada di sekolah. Guru agama harus menjadi model dalam berkarakter di hadapan para siswa dalam berbagai hal, terutama karakter-karakter yang ditargetkan, seperti kereligiusan, kejujuran, kecerdasan, ketangguhan, kepedulian, dan kedemokratisan.

Dalam aktivitas sehari-hari di kelas dan sekolah khususnya dan di luar sekolah umumnya, guru harus menjadi model berkarakter di hadapan para siswa. Karena itu, guru PAI harus menunjukkan kejujuran di hadapan para siswa, memiliki kecerdasan yang tinggi terutama terhadap kompetensi-kompetensi PAI, memiliki ketangguhan untuk mendidik dan berdakwah, memiliki kepedulian dan tangguh jawab yang tinggi, harus demokratis dalam proses pembelajaran di kelas, dan menunjukkan karakterkarakter mulia lainnya di hadapan para siswa. Guru juga bisa menunjukkan beberapa model dari tokoh-tokoh berkarakter yang berhasil dalam hidupnya, baik yang masih hidup maupun yang sudah meninggal dunia. Misalnya untuk memotivasi siswa agar jujur, guru memodelkan Nabi Muhammad saw., agar siswa cerdas, guru memodelkan Prof. Dr. Ing. Habibie, dan lain sebagainya.

\section{Pembelajaran Afektif}

Pembelajaran afektif adalah model pembelajaran yang menekankan tumbuhnya sikap pada diri peserta didik dari proses pembelajaran yang diikuti. Dalam pembelajaran model ini peserta didik antara lain diminta untuk berinteraksi dengan sumber-sumber belajar agar mencapai hasil belajar yang baik. Guru selalu memberi motivasi kepada peserta didik agar menyadari apa yang dipelajari dan mensikapinya dengan benar. Dalam beberapa kasus, pembelajaran sikap merupakan tujuan atau sasaran utama dari suatu pembelajaran.

Kampanye anti-narkoba dan pelatihan-pelatihan yang berkaitan dengan penanganannya misalnya, adalah contoh dari model pembelajaran ini. Sebagai contoh 
dalam pembelajaran PAI, peserta didik diajak untuk memerhatikan betapa Allah swt. sudah memberikan kenikmatan yang begitu banyak kepadanya, seperti kelengkapan dan kesempurnaan bentuk fisiknya, sehingga tumbuh kesadaran untuk bersyukur (berterima kasih) kepada-Nya. Bagaimanapun juga, pembelajaran sikap adalah salah satu komponen atau fokus utama dari suatu pembelajaran, terutama dalam rangka pendidikan karakter.

Model pembelajaran afektif yang banyak digunakan adalah sebagai berikut:

\section{a. Model konsiderasi}

Melalui penggunaan model konsiderasi (consideration model) peserta didik didorong untuk lebih peduli, lebih memerhatikan orang lain, sehingga mereka dapat bergaul, bekerja sama, dan hidup secara harmonis dengan orang lain.

Langkah-langkah pembelajaran konsiderasi: (1) menghadapkan peserta didik pada situasi yang mengandung konsiderasi, (2) meminta peserta didik menganalisis situasi untuk menemukan isyarat-isyarat yang tersembunyi berkenaan dengan perasaan, kebutuhan dan kepentingan orang lain, (3) peserta didik menuliskan responsnya masing-masing, (4) peserta didik menganalisis respons peserta didik lain, (5) mengajak peserta didik melihat konsekuesi dari tiap tindakannya, (6) meminta peserta didik untuk menentukan pilihannya sendiri.

\section{b. Model pembentukan rasional}

Model pembentukan rasional (rational building model) bertujuan mengembangkan kematangan pemikiran tentang nilai-nilai.

Langkah-langkah pembelajaran rasional: (1) menigidentifikasi situasi di mana ada ketidakserasian atau penyimpangan tindakan, (2) menghimpun informasi tambahan, (3) menganalisis situasi dengan berpegang pada norma, prinsip, atau ketentuan yang berlaku dalam masyarakat, (4) mencari alternatif tindakan dengan memikirkan akibatakibatnya, (5) mengambil keputusan dengan berpegang pada prinsip atau ketentuan legal dalam masyarakat.

\section{c. Klarifikasi nilai}

Klarifikasi nilai (value clarification model) merupakan pendekatan mengajar dengan menggunakan pertanyaan atau proses menilai (valuing process) dan membantu peserta didik menguasai keterampilan menilai dalam bidang kehidupan yang kaya nilai. 
Penggunaan model ini bertujuan, agar para siswa menyadari nilai-nilai yang mereka miliki, memunculkan dan merefleksikannya, sehingga para peserta didik memiliki keterampilan proses menilai.

Langkah-langkah pembelajaran klarifikasi nilai: (1) pemilihan: para peserta didik mengadakan pemilihan tindakan secara bebas, dari sejumlah alternatif tindakan mempertimbangkan kebaikan dan akibat-akibatnya, (2) menghargai pemilihan: peserta didik menghargai pilihannya serta memperkuat dan mempertegas pilihannya, (3) berbuat: peserta didik melakukan perbuatan yang berkaitan dengan pilihannya dan mengulanginya pada hal lainnya.

\section{d. Pengembangan moral kognitif}

Perkembangan moral manusia berlangsung melalui restrukturalisasi atau reorganisasi kognitif, yang berlangsung secara berangsur melalui tahap prakonvensi, konvensi, dan pascakonvensi. Model ini bertujuan membantu peserta didik mengembangkan kemampauan mempertimbangkan nilai moral secara kognitif.

Langkah-langkah pembelajaran moral kognitif: (1) menghadapkan peserta didik pada suatu situasi yang mengandung dilema moral atau pertentangan nilai, (2) peserta didik diminta memilih salah satu tindakan yang mengandung nilai moral tertentu, (3) peserta didik diminta mendiskusikan/menganalisis kebaikan dan kejelekannya, (4) peserta didik didorong untuk mencari tindakan-tindakan yang lebih baik, (5) peserta didik menerapkan tindakan-tindakan tersebut.

\section{e. Model nondirektif}

Para peserta didik memiliki potensi dan kemampuan untuk berkembang sendiri. Perkembangan pribadi yang utuh berlangsung dalam suasana permisif dan kondusif. Guru hendaknya menghargai potensi dan kemampuan peserta didik dan berperan sebagai fasilitator/konselor dalam pengembangan kepribadiannya. Penggunaan model ini bertujuan membantu peserta didik mengaktualisasikan dirinya.

Langkah-langkah pembelajaran nondirektif adalah: (1) menciptakan sesuatu yang permisif melalui ekspresi bebas, (2) pengungkapan peserta didik mengemukakan perasaan, pemikiran, dan masalah-masalah yang dihadapinya, guru menerima dan memberikan klarifikasi, (3) pengembangan pemahaman (insight), peserta didik mendiskusikan masalah, guru memberikan dorongan, (4) perencanaan dan penentuan keputusan, peserta didik merencanakan dan menentukan keputusan, guru memberikan 
klarifikasi, (5) integrasi, peserta didik memperoleh pemahaman lebih luas dan mengembangkan kegiatan-kegiatan positif.

\section{F. Kesimpulan}

Pendidikan karakter adalah sebuah sistem untuk mengembangkan nilai-nilai karakter siswa yang meliputi komponen pengetahuan, kesadaran atau kemauan, dan tindakan untuk diimplementasikan ke dalam agama, diri sendiri, masyarakat umum, lingkungan, dan bangsa sebagai manusia yang paripurna. Dalam pelaksanaan pendidikan karakter di sekolah, setiap stakeholder pembelajaran harus terlibat dalam proses tersebut, termasuk komponen pendidikan, yaitu kurikulum, pembelajaran dan proses evaluasi, kualitas hubungan, penanganan pelajaran atau manajemen, manajemen sekolah, pelaksanaan kegiatan ko-kurikuler, penggunaan fasilitas, pendanaan, dan kinerja dari setiap dan semua komponen sekolah.

Pengembangan pendidikan karakter dalam pembelajaran PAI pada sekolah menengah dapat diimplementasikan dengan pengembangan 17 karakter utama, yaitu: kereligiusan, kejujuran, kecerdasan, ketangguhan, tanggung jawab, kepedulian, kedemokratisan, kesantunan, kedisiplinan, cinta ilmu, keingintahuan, percaya diri, menghargai keberagaman, kepatuhan terhadap aturan sosial, gaya hidup sehat, kesadaran akan hak dan kewajiban, dan kerja keras.

Untuk merealisasikan nilai-nilai karakter dalam diri siswa Sekolah Menengah dalam kehidupan sehari-hari baik di sekolah maupun di luar sekolah, bisa ditempuh melalui berbagai bentuk pendekatan pembelajaran yaitu Pembelajaran Kontekstual (Contextual Teaching and Learning), Pembelajaran Kooperatif (Cooperative Learning), Pembelajaran Inkuiri (Inquiry Learning), Pembelajaran Model PAKEM (Pembelajaran Aktif, Kreatif, Efektif, dan Menyenangkan), Pemodelan, dan Pembelajaran Afektif (Model konsiderasi, Model pembentukan rasional, Klarifikasi nilai, Pengembangan moral kognitif dan Model nondirektif). 


\section{Daftar Pustaka}

\section{Referensi Utama:}

Agboola, Alex and Chen Tsai, Kauni. (2012). "Bring Character Education into Classroom”. European Journal Of Educational Research. 1,(2), 163-170.

Guidry, Allen O. (2008). "Character Education Through a Reflective Moral Inquiry: A Revised Model that Answers Old Questions". Journal of Curriculum and Instruction (JoCI), 2, (1), 21-37.

\section{Referensi Pendukung:}

Agung, Leo. (2011). "Character Education Integration In Social Studies learning" HISTORIA International Journal of History Education. XII, (2), 392-403.

Akhwan, Muzhaffar. (2011). Pendidikan Karakter: Konsep dan Implementasinya dalam Pembelajaran di Sekolah/Madrasah. Yogyakarta: Makalah

Daradjat, Zakiah. (1992). Ilmu Pendidikan Islam. Jakarta: Bumi Aksara.

Depdiknas. (2003). Kurikulum 2004 Standar Pendidikan Agama Islam Sekolah Menengah Atas dan Madrasah Aliyah. Jakarta: Pusat Kurikulum Balitbang Depdiknas.

Kementerian Pendidikan Nasional RI. (2010). Panduan Guru Mata Pelajaran Pendidikan Agama Islam: Pendidkan Karakter Terintegrasi dalam pemeblajaran Di Sekolah Menengah Pertama. Jakarta: Kemendiknas.

Harefa, A.(2009). Pengertian Karakter, tersedia dalam http://kabarmu.blogspot.com/2009/05/pengertian karakter.html. downloaded on April 04th, 2013.

Komalasari, K. (2011). Pendidikan Karakter; Strategi Mendidik Anak di Zaman Global. Jakarta: PT Granedia Widisarana Indonesia.

Lickona, T. (1991). Educating for Character; How our School can Teach Respect and Responsibility. New York: Bantam Books.

Megawangi, R. (2004). Pendidikan Karakter Solusi yang Tepat Untuk Membangun Bangsa. Jakarta: Indonesia Heritage Foundation.

Sauri, S.(2010). Membangun Karakter Bangsa Melalui Melalui Pembinaan Profesionalisme Guru Berbasis Pendidikan Nilai. Journal Pendidikan Umum dan Nilai.

Sumantri, E. (2010). "Pendidikan Budaya dan Karakter suatu Keniscayaan Bagi Kesatuan dan Persatuan Bangsa", dalam Pendidikan Karakter : Nilai Inti bagi Upaya Pembinaan Kepribadian Bangsa, Bandung: Widya Aksara Press.

Suyanto . (2006). Dinamika Pendidikan Nasional Dalam Percaturan Global Dunia. Jakarta : PSAP Muhammadiyah. 